\title{
CLEC11A wt Allele
}

National Cancer Institute

\section{Source}

National Cancer Institute. CLEC11A wt Allele. NCI Thesaurus. Code C116595.

Human CLEC11A wild-type allele is located in the vicinity of 19q13.3 and is approximately

$2 \mathrm{~kb}$ in length. This allele, which encodes C-type lectin domain family 11 member A protein, is involved in the positive regulation of both proliferation and differentiation of hematopoietic cells. 